Article

\title{
Bridging the Gap: Making Sense of the Disaccord between Migrants' Education and Occupation
}

\author{
Anica Waldendorf ${ }^{1,2}$ \\ ${ }^{1}$ Centre on Migration, Citizenship and Development, Faculty of Sociology, Bielefeld University, 33615 Bielefeld, Germany; \\ E-Mail: anica.waldendorf@uni-bielefeld.de \\ 2 Department of Political and Social Sciences, European University Institute, 50014 Fiesole, Italy; \\ E-Mail: anica.waldendorf@eui.eu
}

Submitted: 14 August 2020 | Accepted: 7 October 2020 | Published: 18 February 2021

\begin{abstract}
Social mobility is a central topic of interest within sociology and whilst it has been theoretically linked to spatial mobility, there is still little empirical research on the interplay between the two. Using a subsample of highly educated family migrants from a German mixed-methods project, this study qualitatively analyses the impact of geographical mobility on objective social position and on its subjective perception. Six qualitative interviews are analysed and supplemented with descriptive quantitative data from the German Socio-Economic Panel to firstly, reconstruct the spatial mobility trajectories of the individuals and secondly, determine their social position in Germany and ascertain whether they experienced occupational downgrading. These two analyses are integrated to explore how respondents experienced their change in social position. Across the board, respondents migrated as young adults, before or shortly after labour market entry. Five of the participants experienced occupational downgrading. Strikingly, this objective downgrading, whilst acknowledged, was not perceived negatively. The participants constructed a narrative that employed three legitimation strategies to cast their current social position in a positive light: (1) emphasising the rights, stability and security that they experience in Germany, (2) drawing attention to the economic improvement that they experienced and (3) displaying an inner attitude that is marked by modest life aspirations and a high regard for leisure time. By drawing on multinational frames of reference and thus drawing comparisons between their home country and Germany, participants highlighted the experienced benefits.
\end{abstract}

\section{Keywords}

family migration; Germany; highly educated migrants; mobility; social mobility

\section{Issue}

This article is part of the issue "Migration and Unequal Social Positions in a Transnational Perspective," edited by Thomas Faist (Bielefeld University, Germany).

(C) 2021 by the author; licensee Cogitatio (Lisbon, Portugal). This article is licensed under a Creative Commons Attribution 4.0 International License (CC BY).

\section{Introduction}

Studies on social status and social mobility are a central topic in sociology. Different strategies may be used to change one's social position. One strategy can be to use spatial mobility in the form of cross-border migration to increase one's social position as it "holds the promise of upward social mobility" (Faist, 2019, p. 65). However, the idea of using spatial mobility to be socially mobile does not always translate into reality. Chiswick,
Lee, and Miller (2005) found that migrants in Australia experienced a "U-shaped pattern of occupational mobility": A drop in occupational position after migration, followed by an increase again over time (Chiswick et al., 2005 , p. 348). Whilst this U-shaped pattern of occupational mobility has also been found in the United States (Akresh, 2008), migrants in other countries, such as Spain (Fernández-Macías, Grande, del Rey Poveda, \& Antón, 2015; Simón, Ramos, \& Sanromá, 2014) and Italy (Barbiano di Belgiojoso, 2019), have been found to expe- 
rience downward social mobility without a subsequent increase in occupational position, which possibly reflects structural differences in labour markets.

The strength of this decline and potential subsequent increase in occupational position depends on several factors. For example, the path of entry into the country of destination, the level of skill and the transferability of skills-economic migrants and more skilled migrants (here skills also refer to language skills) experience a smaller decline in occupational position (Chiswick et al., 2005, p. 348). Education (Akresh, 2008; FernándezMacías et al., 2015; Vidal-Coso \& Miret-Gamundi, 2014) and language (Akresh, 2008; Esser, 2006; Henkelmann, 2012) have been found to play a mitigating role: People with higher levels of education and language skills are less likely to experience downward social mobility. However, some studies also find that spatial mobility leads to downward social mobility, despite someone's high level of education (Jungwirth, 2014; Liversage, 2009; Nohl, Ofner, \& Thomsen, 2010; Vianello, 2014). This is due to, for example, qualifications not being recognised or valued (Nohl et al., 2010, pp. 74-75), resulting in downward social mobility. Thus, there is both evidence that especially highly educated individuals experience a decline in their social position and evidence that education protects against downward mobility.

Family migration, which is said to favour occupational downgrading (Chiswick et al., 2005, p. 348), is distinct from other forms of migration as the structural and personal conditions are likely to be different. For example, Liversage $(2009$, p. 136) finds that the women she interviewed struggled to combine their family oriented migration with their high-skilled careers:

If such women [who migrate to be with their partner] subsequently face grave labour market difficulties, these difficulties spring from the intersection of the spheres of family and work-of trying to rebuild careers in a place to which they came only for family reasons.

Someone who comes to a country through family migration has a different access to the job market and different barriers than someone who comes with a job contract. Furthermore, the personal situation of migrating for family reasons suggests that one has obligations towards family members and cannot act in isolation but has to take into account partners and perhaps children when making decisions.

Thus, there are different factors that potentially influence one's social position after migration. It is often overlooked that one person can embody more than one of these characteristics. As Eleonore Kofman (2012, p. 65) argues: "Skilled migrants are studied through the prism of labour migration whilst the world of family migration is categorized as social, in which skills would seem irrelevant and of little interest." The combination of family migration and being highly educated provides an inter- esting, potentially conflicting combination: What happens when one person is both a family migrant and highly educated?

Moreover, when considering the social mobility of migrants, it is important to pay attention to the international framing of social position and relativization. Rather than comparing oneself to others in the receiving country, comparisons may be made based on one's own previous situation in the sending country (e.g., Favell \& Recchi, 2011; Vianello, 2014). Therefore, although migration might result in an objectively lower social position in the receiving country, it might not be perceived as such due to the frame of reference being the sending country. Hence, taking a closer look at how these two different characteristics - being a family migrant and being highly educated-impact the objective social position and its perception deserves further attention.

This study examines the social positions of universityeducated men and women who migrated to Germany for family reasons. Specifically, migrants' social positions are analysed from two perspectives: Their occupational class position as well as their subjective perceptions of their current social position. Focusing on these two perspectives offers a complementary view on spatial mobility and social mobility.

In order to do so I analyse qualitative interviews from the mixed-methods project "Transnational Mobility and Social Positions in the European Union." This analysis is supplemented by descriptive data from the Socio-Economic Panel (SOEP). The class position of six highly educated family migrants in Germany is determined by using the Erikson-Goldthorpe-Portocarero (EGP) scheme. The current EGP value is then contrasted against the participants' university level education and their own perception of their social position, which is garnered from the qualitative interview material.

The following section describes the data and methods used. After introducing the six participants, the general characteristics of their spatial mobility trajectories are described. Subsequently, their social position in terms of social class is determined. The section ends with an analysis of their perception of their social position and the legitimation strategies they engage in.

\section{Methods}

This study uses data from the "Transnational Mobility and Social Positions in the European Union" project. The project was conducted at Bielefeld University with Professor Thomas Faist as the principal investigator and funding from the German Research Foundation. It ran for three years (2016-2019), with data collection taking place in 2017. The project's objective was to analyse spatial mobility trajectories with respect to different heterogeneities and to consequently link these trajectories to objective and subjective social positions (Sienkiewicz, Tucci, Barglowski, \& Faist, 2017). A key feature of the data is the record linkage between the 
qualitative and quantitative data: SOEP respondents were sampled for the qualitative interviews. This linkage of longitudinal survey data with qualitative survey data is a unique feature which allows the use of both sources of information. The qualitative data was collected using semi-structured interviews that included narrative elements as well as participatory exercises (see Supplementary File). The quantitative data stems from the migration sample in the SOEP (v34) in Germany, which is a representative annual household survey (Kroh, Kühne, Goebel, \& Preu, 2015; Wagner, Göbel, Krause, Pischner, \& Sieber, 2008).

Six participants were selected from the thirty-seven available qualitative interviews based on two criteria: moving to Germany for family reasons and having a university degree. Importantly, migration for family reasons here refers to the subjective reason for migration as stated in the interviews, rather than being admitted to Germany for family reasons. The latter refers to the legal grounds for residence in Germany. The former sample selection criterion was used because the interest of this research is in the experience of migration and subsequent class position of those whose migration was motivated by family reasons.

Secondly, highly educated persons, defined as those who have a university education, were selected. The information on the level of education also stems from the qualitative interviews. Additionally, the spatial mobility had to have taken place as an adult to take into account the effect of educational credentials that have been obtained abroad as well as potential labour market experience obtained outside of Germany.

Eleven respondents fit these two criteria. Of these, six interviews were selected based on whether the interviewee discussed his or her occupational life and career in the interview. These six interviewees, while being homogeneous in their motivation for migration and their educational level, vary in their origins (from within or outside the European Union) as well as being able to migrate freely or being forced to flee from their home countries. This way, the interviews provide insights into the diversity and commonalities of the experiences of highly educated family migrants in Germany. Despite this heterogeneity in the participants' backgrounds, common patterns can be identified, indicating that a certain level of theoretical saturation has been reached. All six participants were in a heterosexual relationship when they migrated.

A secondary analysis of the six interview transcripts using open coding was conducted. The process of open coding as described by Strauss (1987, pp. 28-32) was taken as a guideline and adapted to reflect the nature of the present data. The qualitative data analysis software MAXQDA (Version 18.2.0) was used to code the interview material. Descriptive coding was used to enable the reconstruction of the spatial mobility trajectories and to determine class position before migration. All data has been anonymised and pseudonyms are used. Both the level of education and the occupational position were available in the SOEP data.

The respondent's class is determined using the sevenclass variation of the EGP scheme, which is a categorical class scheme that determines someone's class on the basis of their occupation (Erikson, Goldthorpe, \& Portocarero, 1979). The seven classes are: the service class, routine non-manual workers, the petty bourgeoisie, farmers, skilled manual workers, non-skilled manual workers and agricultural labourers (Erikson \& Goldthorpe, 1992, pp. 38-39). Drawing on Weber, a distinction is made between positions in the labour market based on a "labour contract" and positions that are based on a "'service' relationship" (Erikson \& Goldthorpe, 1992, pp. 41-42). The former is a rather direct, short-term exchange of labour for wages whereas the latter is more long-term oriented, and labour is provided in exchange for wages as well as job stability, independence at work and other benefits (Erikson \& Goldthorpe, 1992, pp. 41-42). Service class positions include, for example, "professionals, administrators and managers" whilst routine non-manual workers are, for example, "sales personnel" or "other rank-and-file service workers" (Erikson \& Goldthorpe, 1992, pp. 38-39). Groups of occupations are delineated based on similar work environments and working conditions, as opposed to the income or prestige that a certain occupation is linked to (Erikson et al., 1979, p. 416). By focusing on objective working conditions that characterise the occupations in different classes, the classes distinguished by the EGP scheme affect individuals' long-term life chances. Furthermore, those with the same class position share common social and economic interests, contributing to class formation also in a subjective sense in a way that is not captured by hierarchical measures of socioeconomic status (Erikson \& Goldthorpe, 1992, p. 31-32).

Although this article uses a qualitative approach it also includes some descriptive quantitative data, for example, to reconstruct the spatial mobility trajectories. The data stem from the questionnaire which the participants filled out in their first year of participation in the SOEP, in this case either 2013 (participants from migration sample 1) or 2015 (participants from migration sample 2). Their migration history data was retrospectively collected using the questions from the section "How You Came to Germany" in the SOEP data (TNS Infratest Sozialforschung, 2014, pp. 6-8, 2016, pp. 72-77). This section includes questions about the country of past moves and stays abroad of periods of three months or more and the month and year of these moves (see Supplementary File).

The information on the EGP position of each individual is included in the SOEP as a generated variable that indicates the last reached EGP value. This means that the SOEP has coded the information on occupational position provided by the respondents and correspondingly determined the EGP value by also drawing on information on income and education (on how the 
EGP value is created see SOEP Group, 2018, pp. 22-23). The International Socio-Economic Index of Occupational Status (ISEI) value is also generated by the SOEP and made available in its dataset (SOEP Group, 2018, pp. 18-19). Both the ISEI and the EGP are generated on the basis of the International Standard Classification of Occupations (ISCO).

\section{Description of the Participants}

Mariam is a middle-aged woman from Iraq who migrated at the end of the 1990s in her early twenties, passing through Turkey and staying there for an extended period of time. Her husband, who is Iraqi, had fled to Germany several years earlier. She completed her degree in Iraq before moving to Germany. She has held various positions in Germany.

Zlata moved to Germany from the Ukraine after marrying her husband, who is German, in her late twenties. She has now lived in Germany for close to 20 years. She is employed in the field of early childhood education, which is also the field of her degree, yet she is employed at a markedly lower level.

Maja moved to Germany in her late twenties from Poland to be with her Polish boyfriend who lived and worked in Germany. She has lived in Germany for just over five years. Although she and her boyfriend have split up, she has decided to stay in Germany, where she works as a shop sales assistant.

Balian moved to Germany from Turkey in his midtwenties to live with his Turkish wife who was living in Germany, over twenty years ago. He worked in different fields in Germany before gaining vocational training in a different field and is now a logistics manager.

Toma was born in Bulgaria and has experienced multiple moves between different countries. His first migration took place in his late twenties. In his mid-thirties he followed his Romanian wife, who had a job in Germany, to Germany, where he has lived for less than 5 years. $\mathrm{He}$ has held various jobs, all of which were not in the field of his university degree. Currently, he is a manual labourer.

Matei was born in Romania and has lived in several countries. He moved to another German speaking country in his mid-twenties, where he lived for several years. Less than five years ago, when he was in his mid-thirties, he moved to Germany to be with his Romanian girlfriend, who was employed in Germany. He has a degree in information technology and is employed in this area.

\section{Description of Spatial Mobility Trajectories}

Knowing the spatial mobility history of a person and reconstructing their previous movements is important for trying to understand their class position. For example, Jungwirth (2014, p. 220) points out that many of the women she interviewed migrated as young adults when their careers were still being established. Therefore, the spatial mobility trajectories of the six participants were reconstructed based on the descriptive information provided in the qualitative interviews and the available SOEP data. The spatial mobility trajectories can be described according to three characteristics: The duration, the timing and the space of the mobility. It is important to bear in mind that all the participants were sampled as family migrants, meaning that they moved to Germany to be with their partner, not because they had a job offer. This may negatively impact their occupational position despite being highly educated (e.g., Liversage, 2009).

Regarding the duration of the spatial mobility experience three aspects stand out. Firstly, for half of the participants, the move to Germany is the first and only crossborder move, thus signalling the long-term orientation of the move. Secondly, the move was nonetheless not seen as final and irreversible. Thirdly, in a number of cases pendular spatial mobility (meaning going back and forth between two countries) was engaged in prior to the actual cross-border move, thus there was a gradual increase in spatial mobility leading up the move.

Two aspects stand out regarding the timing of becoming mobile. Firstly, the initial migration from one's country of origin occurs in early adulthood. Strikingly, in all cases the first move occurred when the person was in their twenties, shortly before or just after labour market entry. This mirrors the findings of Jungwirth (2014) and Nohl et al. (2010). In the case of Toma and Matei there is some spatial mobility later on, yet it still occurs in their early to mid-thirties. Noticeably, all but one of the participants were childless at the time of their first spatial mobility. The age of migration is crucial for the migration decision in relation to their career, family planning and children, and the amount of sacrifice involved (i.e., what capital they have accumulated and would potentially need to give up when they become mobile; see, for example, Fernández-Kelley, 2008; Nowicka, 2013).

With regard to space, all the participants move from an economically weaker country to Germany, an economically strong country. It was also important whether someone migrated to an urban or a rural space. According to Matei and Toma, urban spaces offer more professional opportunities. In contrast, Maja and Mariam highlight increased freedoms in relation to their gender by describing the prevalence of traditional gender norms (getting married and having children) in smaller towns and rural areas, compared to urban cities.

\section{The Contradiction between Education and Occupational Position}

There is a visible gap between the formal level of education and the occupation held. Considering the tertiary education that all participants have completed, it is striking that the majority of participants neither work in their field of education, nor hold an occupational position that could be expected for someone with their level of education. Only one of the participants (Matei) works in 
the field in which he trained and holds what could be described as an occupational position that reflects his level of education. The other participants either work in an entirely unrelated field (Mariam, Toma, Maja, Balian) or in the same field of work but at a markedly lower level (Zlata).

To understand class position in comparison to education, the position of German born people with a university education can be used as a reference. In 2017, 74.6\% of native-born Germans with a university education and no migration history were employed in a service class occupation (as mentioned above, these are, for example, "professionals, administrators and managers" (Erikson \& Goldthorpe, 1992, p. 39). $13.6 \%$ were employed in routine non-manual work, for example, "sales personnel" and "other rank-and-file service workers" (Erikson \& Goldthorpe, 1992, p. 39) and only $3.5 \%$ in skilled manual work, for example, "lower-grade technicians" and "supervisors of manual workers" (Erikson \& Goldthorpe, 1992, p. 38; own calculations using SOEP, 2019, survey year 2017). Thus, a service class level occupation can be seen as typical for someone with a university education. However, of the six participants, only Matei is employed in a service class occupation. Mariam, Zlata, Maja and Balian are employed in routine non-manual work occupations and Toma is a skilled manual worker (this classification is based on SOEP, 2019, survey year 2017). This mismatch between the respondents' education and occupational position holds when a different measure, the ISEI (which is a measure of social-economic status; see Ganzeboom, de Graaf, \& Treiman, 1992), is used. ISEI values range between 16 and 90 and a low value represents a lower social position and a high value a higher social position. Whilst native born Germans with a university education had a mean ISEI value of 59 in 2017, the ISEI value of the participants ranged between 25 (Mariam) and 52 (Matei; own calculation using SOEP, 2019, survey year 2017). Thus, both the ISEI and the EGP values of the participants are below what might be expected. Maja is a trained social worker and works as a shop sales assistant (EGP = routine non-manual work; ISEI = 43); Zlata is an early childhood educator, which is on the same level as a teacher in her home country, and works in the field of child care (EGP = routine nonmanual work; ISEI = 43); Mariam has a degree in German and has worked in the field of care work (EGP = routine non-manual work; ISEI = 25); Balian has a degree within the field of tourism and works as a logistics manager (EGP = routine non-manual work; ISEI = 32); Toma has a degree in finance and works as a manual labourer (EGP = skilled manual worker; ISEI = 33). Only Matei works in IT, the field in which he has a university degree (EGP = service class; ISEI $=52$ ). These positions are lower than what would be expected, thus they (with the exception of Matei) experience an objective occupational downgrading.

This quantitative finding of occupational downgrading is mirrored in the qualitative interview material. All three women and also Toma describe the experience of occupational downgrading. All four describe the experience of not working in a position that corresponds to their level of education or equal to the position that they once held in their country of origin (if they were employed before moving to Germany). Thus, it is not just an objective, external analysis that occupational downgrading occurred; the interviewees are conscious of the fact that their class position has changed, as the following quote from Zlata demonstrates:

Also, for me that [was] difficult, back then I had to accept it, I had to slide down, change my social level, I was higher, but different also cannot be.

Balian is the only person who does not describe this experience of occupational downgrading despite objectively undergoing it. He nonetheless engages in and uses the same legitimation strategies employed by those participants who do (initially) observe a downgrading.

To understand the subjective perception of the objective downgrading it needs to be located in a transnational context by considering the class position and social background of the individual in their country of origin before migrating, not just their achieved level of education. Only Zlata, Maja and Matei were employed in their field before migrating. In contrast, Balian and Mariam migrated immediately after having finished their studies, so they did not enter the workforce in their home country. Toma left his field of work whilst still in his country of origin. Maja and Zlata emphasise their downgrading the most and they are also the ones who experience the sharpest contrast because they were the only ones who had worked in their field in their home country. Balian does not subjectively experience occupational downgrading because he did not work in his field in Turkey. He therefore does not experience it as a 'loss' to not work in his field in Germany.

Two factors can be identified as contributing towards the experience of occupational downgrading: Firstly, language proficiency and secondly, the labour market environment in Germany, especially the (lack of) recognition of qualifications. In addition, adaptation difficulties that are not directly related to one's occupation are encountered and may potentially hamper achieving one's expected occupational position, at least initially.

This occupational downgrading is in line with previous studies that indicate that particularly highly educated migrants are liable to experience occupational downgrading, due to, for example, qualifications not being recognised (e.g., Jungwirth, 2014, p. 217; Nohl et al., 2010, pp. 74-75). It is only Matei who is protected from occupational downgrading, but this is due his "highly transferable skills," rather than his education per se (Chiswick et al., 2005, p. 348). The prohibitive factor of language proficiency is also not surprising and mirrors the findings in the literature (e.g., Akresh, 2008; Esser, 2006). 


\section{Legitimation Strategies to Compensate for Occupational Downgrading}

In light of the downgrading that objectively takes place, it is interesting to see how the participants perceive this downgrading, what meaning they attach to it and how they frame it. Strikingly, they are aware of their objective downgrading but do not appear to mind. They tell a story that focuses on the advantages that they have through having been mobile. Although they do mention the downsides, including the sacrifices they have made and difficulties they have faced, they nonetheless see themselves as being better off for having been mobile. This is especially vivid in the case of Zlata:

Well that is not so high level. Let me put it this way....My thirty years I have in other country spent, and I can't expect that I have here the same position as in other country. Of course luck may play a role, but, yes, I am content.

Though she knows that she has a "not so high level," she is content. Similarly, some of the participants (Maja, Balian) emphasised that they could or would move back to their home country if they did not like it in Germany. Yet they remained in Germany, signalling a beneficial position in Germany. Despite the disaccord between their education and their occupational position in Germanyand their awareness of this-they decided to stay in Germany: "I-actually I like here, right. If I'm so bad, then I go back to Poland, right." (Maja) This constructs a narrative of agency and self-determination: Maja chooses to stay rather than having no choice. The fact that they stayed in Germany while potentially having the possibility to migrate back to their home country underscores that Germany provided them with something that they could not achieve in their home country that is more important to them personally than their class position. Moreover, it must be considered that their framing of their position is based on their family life: If they were to migrate again it would affect not just them, but also their partner and their children. Three different legitimation strategies are employed to bridge the gap between the objective occupational downgrading and the subjectively perceived improvement of their position.

\subsection{Rights, Security and Stability}

One legitimation strategy is centred around the benefits that are experienced in Germany, in particular the rights and newfound security and stability that several participants enjoy in Germany. By comparing their current situation in Germany to their previous situation in their home country, they emphasise the great benefit of having certain employment rights:

[In my home country] When you say, hey, insurance, then he [employer] says 'Here you go, there are hun- dreds waiting outside the door, either or.' So that, for example, I became aware of, [here in Germany] I can speak out, if it is wrongful, if it does not suit me, so I somehow have more rights, for example annual leave, that wasn't the case, right. Oh, suddenly I have annual leave, I can go away. Or when I am ill, nothing happens to me, no one will throw me out. (Balian)

Similarly, Toma describes being "allowed" to be ill, which clearly demonstrates the great freedom and security provided by having more employment rights in Germany. This makes it worthwhile to stay in Germany. Mariam explicitly states that she would very likely have a higher class position in her home country and consciously engages in a trade-off to be able to enjoy the right of free speech in Germany. Zlata uses the example of pensioners in Germany to highlight the experience of having increased rights in Germany. She explains that pensioners are well off because they can rely on receiving support if they are ill. Thus, there is a trade-off between working in one's occupation and securing rights that cannot be obtained in one's home country.

Additionally, the interviewees believe that Germany provides a meritocratic system in which individual effort and hard work is rewarded, something which both Matei and Toma emphasise. The idea is that one knows that if one works towards something and achieves a certain level, then one can be confident that one will be able to have a certain position. In contrast, in their home countries of Romania and Bulgaria respectively, the position one has is determined by political party membership (Matei), social contacts (Matei, Toma) and corruption (Toma). Thus, Zlata, Mariam, Toma, Balian and Matei all address the possibility of having more rights, stability and security in Germany.

Similarly, Barbiano di Belgiojoso and Ortensi (2019, p. 2545) show that migrants are satisfied with their jobs "if basic decent working conditions are guaranteed." Although their analysis is not limited to highly educated migrants, it is nonetheless in line with the experience of employment rights enabling the participants to perceive their subjective position positively.

Nation states provide an important structuring element of people's lives by providing certain "public goods" that benefit everyone favourably (Weiss, 2006). Germany as a nation state provides the participants with a stable political system and a welfare state system that imbues its members with certain rights. This has a positive effect on the participants, independent from their own occupational (and financial) position.

\subsection{Economic Improvement}

A second legitimation strategy relies on the emphasis of the improvement in one's economic situation. Toma, Balian, Matei, Maja and Zlata all construct a narrative which points out their economic improvement. There are two sides to this: Germany provides higher wages than 
the home country or living costs are lower in Germany, thus the purchasing power is higher, and a different living standard can be achieved with the same income. This allows someone to work in a different occupation yet still have a higher standard of living. Working in one's occupation is 'sacrificed' because Germany provides a context in which the money earnt in a lower position is still more than sufficient. Toma emphasises: "I am more satisfied due to [the fact that] I have more money, and I can, how to say, simply live a normal life." Germany also offers better job prospects according to Toma, Zlata and Balian.

When considering the economic situation of the participants it is important to take their partner's economic situation into account and thus to consider the household level. For example, Zlata herself does not earn a lot of money in her part-time job but this is offset by her husband who is the breadwinner. The information provided in the interviews and the answers in the SOEP regarding income show that the participants do have a certain economic security. Maja, who is the only person who is single, also has the lowest household income, yet she still says that she has enough money to save a little bit every month. Therefore, the participants' narrative of being economically better off in Germany is supported by the information on their financial situation.

The economic improvement experienced is due to the local differences in the value of resources that become apparent in the comparisons that migrants draw between the country they are living in and their home country. They compare the value of goods in both of these contexts. This is what Weiss $(2002$, p. 3 ) calls the "spatial relation" (translation by author) of the value of resources. The value of a resource varies depending on the context in which it is appraised, the quantity of the resource and the role that it plays in the given environment (Weiss, 2002, pp. 4-5). In short, the same good is valued differently in one country compared to another. By drawing comparisons to their home country, the participants demonstrate how the same resource, in this case money, has a different value in different spaces, in this case different nation states. Maja exemplifies this using the example of her income in relation to the cost of living: "But normally-now I am alone and I can pay for everything by myself. And in Poland that is impossible. Then everything that I can earn I must spend on my flat. Everything." Balian and Matei also compare the costs of consumption goods in Germany and their home countries. Not only do the participants have more money, but what they can purchase with it is also different.

The partner's position is a unique characteristic of family migration that needs to be taken into account to understand the positive narrative of the participants' subjective position. The participants moved to Germany to be with their partner, who was already established in Germany, and in most cases had a secure job. This played an important role in deciding which partner was to migrate for Toma, Matei and Zlata. For example, Matei describes how once the decision that either he or his wife would migrate was made, they actively discussed their respective employment options in their partner's country before deciding that Matei would move to Germany because of his favourable employment prospects there. Thus, employment opportunities, which are linked to one's economic future, are taken into consideration.

Cederberg (2014, p. 144) also finds that migrants who have experienced occupational downgrading do not necessarily perceive this negatively and argues that the positive perception of their position can in part be due to having a partner from the destination country. As described above, the fact that there is a second person who is already living in the country of destination (regardless of whether they have that nationality or not) is a central characteristic of family migration. This is made explicit in the economic considerations of the participants and also the negotiations of which partner is to migrate to which country. This is a unique characteristic of family migration: There is another person in the household who can contribute towards the household income and who the migrating person can fall back on in case of difficulties. Maja recalls that her boyfriend at the time "helped me a little bit" when she came to Germany. Even though they are no longer together, this likely helped her gain her footing in Germany. The presence of a partner in a stable employment (and thus economic) situation makes the positive subjective position both possible and plausible. Without the support of a partner the spatial move and its consequences may have been very different.

\subsection{Modest but Hard-working Family Oriented Inner Attitude}

A third legitimation strategy expresses an inner attitude that is based on modest life aspirations and that highly values leisure time and time spent with family-parallel to a strong work ethic. The participants emphasise that they are currently content. Whilst found important, hard work is decoupled form the content of the work: Wanting to work is highly regarded in and of itself. Thus, there is a re-orientation away from defining oneself through one's professional life towards focusing on other aspects.

Rather modest life aspirations are put forward. Toma, Balian, Zlata, Maja and Mariam all make it clear that they do not require a lot to be happy. As Zlata states:

So when internally [I] am happy already with something small, then it is already good. So I am not jealous when other people have a little more or so, I really don't care. What I have-so what at all in my eyes what have people, that doesn't need to be a lot. We have food, we can go to the doctors und we also have a house, we are not outside, also in general I think in country there is no war or so, what more do we want.

The other participants have similarly modest desires. They are happy being able to afford small items, such as a pair of trousers or a jacket (Balian), make-up and clothes 
and going for meals with friends (Maja). One important dimension of leisure time is the possibility to go on holiday (Maja, Balian, Toma).

A further dimension of leisure that is important is family time. Maja combines her desire to go on holiday with visiting her family and describes it as a "luxury" to be able to spend time with them. Toma explains that only in Germany has he had the possibility to have a family life. Mariam even goes so far as to say that she is happy to forfeit her own income and incur financial restrictions in order to be able to be there for her family. Family life and time spent with their children is accorded a high priority. This opportunity is afforded to them in Germany because they have the financial basis to do so. The importance of family is already reflected in their migration for family reasons.

In addition, as outlined before, respondents emphasise hard work. Toma and Mariam draw attention to the fact that despite not working in their trained occupation, they nonetheless work hard and this reflects positively on their evaluation of their social status. This is especially visible in the critique of people who do not want to work and are not willing to educate themselves further (Balian, Zlata) and describing phases of unemployment as "the worst" (Toma) and "a catastrophe" (Maja). Further evidence for this high recognition of hard work is revealed in the participatory exercise in which different photos depicting different occupations have to be ranked. When determining the class position of the person and the respective occupation shown in different pictures, Mariam, Maja and Matei consider whether the job involves hard work or not in order to determine their position. Mariam explains this as follows: "They are all at the top for me [laughs]. All do good work. I cannot think anything else, the harder his work is, the more value it has for me. (unclear)....They need to fight to get this position. They need to really fight."

This legitimation strategy can be seen as what Eijberts and Roggeband (2016, p. 135) term a compensating strategy: The participants try and compensate for their lower social class by placing the focus on working hard and stressing their good family life and thus elevating their perception of their position. This is a strategy that other migrants have also been shown to engage in. Both Moroşanu and Fox (2013, p. 448) and Vianello and Toffanin (2020, p. 11) find that when faced with stigmatisation or difficulties in the labour market Romanian migrants focus on the individual level and their hard work. This is also a strategy employed by family migrants interviewed by Cederberg (2014, p. 142) in Sweden. Cederberg (2014, p. 144) warns that there are "social pressures, including precisely the concern to present the self as a 'good migrant,"' which may play a role here.

\section{Conclusion}

This article set out to investigate the class position of university educated migrants who have engaged in spa- tial mobility to be with their partners and also includes their subjective perception of their position. Five out of the six participants were found to have experienced an objective occupational downgrading and most are aware of this. Surprisingly, however, this objective downgrading is not perceived negatively and instead a narrative is constructed in which one's life in Germany is cast in a positive light. Three different legitimation strategies are employed. These strategies are a manifestation of the social-spatial nexus: Whilst the experience of occupational downgrading is due to the spatial move it also provides the participants with different frames of reference which provide the opportunity to construct legitimisation strategies that negate the occupational downgrading. Comparisons are drawn between Germany and their home country, which allows them to see their new position positively, despite its objective decline.

Consequently, using occupational measures to measure class position may not adequately capture class position. It is unclear whether the shift away from defining one's class position through occupation and instead turning towards the private sphere occurs because the desired status cannot be reached in the occupational sphere and is thus sought elsewhere. Moreover, it is important to bear in mind that migrating for family reasons already signals an orientation away from occupation and thus forms a specificity of family migrants. Future research is necessary to pinpoint the mechanism at work-whether the shift away from defining one's position through one's occupation is because of the occupational downgrading experienced or due to a general family orientation.

Additionally, the present study highlights the importance of considering not just the individual level but also the household level by taking into account the position of the partner in cases of family migration. A possible reason for family migrants to perceive their social position positively despite their downward occupational mobility is due to the presence of a partner who is already employed in the country of destination and provides a stable economic base. Without considering the family aspect of highly educated migration an important facet of spatial mobility is obscured. Thus, mobility research needs to be sensitive to the ways that migrants are categorised and be aware of the simultaneity of different categorisations and the impact that this may have.

Multiple other areas for future research can be discerned. Firstly, the spatial mobility within the country of destination after migration deserves further attention. This includes paying attention to the type of region which one migrates to-whether it is rural or urban. Several of the participants indicated that there is a difference between the two, which warrants further investigation. Secondly, this article has only investigated the impact of spatial mobility on social mobility, but the opposite also deserves attention: How does class position impact spatial mobility? Who migrates and who remains immobile? 


\section{Supplementary Material}

Supplementary material for this article is available online in the format provided by the author (unedited).

\section{Acknowledgments}

Thomas Faist and Anna Spiegel provided valuable guidance when I began working on this subject, for which I am very grateful. I also thank Joanna J. Fröhlich and Inka Stock for their support and feedback along the way and the helpful comments that Inka Stock provided on a first draft of this article. I also thank the three anonymous reviewers and Juho Härkönen for their comments. This research uses data from the project "Transnational Mobility and Social Positions in the European Union," which was funded by the German Research Foundation (DFG), project number FA 284/7-1.

\section{Conflict of Interests}

The author declares no conflict of interests.

\section{References}

Akresh, I. R. (2008). Occupational trajectories of legal US immigrants: Downgrading and recovery. Population and Development Review, 34(3), 435-456.

Barbiano di Belgiojoso, E. (2019). The occupational (im)mobility of migrants in Italy. Journal of Ethnic and Migration Studies, 45(9), 1571-1594.

Barbiano di Belgiojoso, E., \& Ortensi, L. E. (2019). Satisfied after all? Working trajectories and job satisfaction of foreign-born female domestic and care workers in Italy. Journal of Ethnic and Migration Studies, 45(13), 2527-2550.

Cederberg, M. (2014). Public discourses and migrant stories of integration and inequality: Language and power in biographical narratives. Sociology, 48(1), 133-149.

Chiswick, B. R., Lee, Y. L., \& Miller, P. W. (2005). A longitudinal analysis of immigrant occupational mobility: A test of the immigrant assimilation hypothesis. International Migration Review, 39(2), 332-353.

Eijberts, M., \& Roggeband, C. (2016). Stuck with stigma? How Muslim migrant women in the Netherlands deal-individually and collectively-with negative stereotypes. Ethnicities, 16(1), 130-153.

Erikson, R., \& Goldthorpe, J. H. (1992). The constant flux. A study of class mobility in industrial societies. Oxford: Clarendon Press.

Erikson, R., Goldthorpe, J. H., \& Portocarero, L. (1979). Intergenerational class mobility in three Western European societies: England, France and Sweden. The British Journal of Sociology, 30(4), 415-441.

Esser, H. (2006). Migration, Sprache und Integration [Migration, language and integration] (AKI Research Paper No. 4). Berlin: WZB Berlin Social Science Center and Programme on Intercultural Conflicts and Societal Integration.

Faist, T. (2019). The transnationalized social question. Migration and the politics of social inequalities in the twenty-first century. Oxford: Oxford University Press.

Favell, A., \& Recchi, E. (2011). Social mobility and spatial mobility. In V. Guiraudon \& A. Favell (Eds.), Sociology of the European Union (pp. 50-75). Basingstoke: Palgrave Macmillan.

Fernández-Kelley, P. (2008). The back pocket map: Social class and cultural capital as transferable assets in the advancement of second-generation immigrants. The ANNALS of the American Academy of Political and Social Science, 620(1), 116-137.

Fernández-Macías, E., Grande, R., del Rey Poveda, A., \& Antón, J.-I. (2015). Employment and occupational mobility among recently arrived immigrants: The Spanish case 1997-2007. Population Research and Policy Review, 34(2), 243-277.

Ganzeboom, H. B. G., de Graaf, P. M., \& Treiman, D. J. (1992). A standard international socio-economic index of occupational status. Social Science Research, 21, 1-56.

Henkelmann, Y. (2012). Migration, Sprache und kulturelles Kapital. Die Relevanz von Sprachkenntnissen bei der Arbeitsmarktpositionierung migrierter Akademikerlnnen [Migration, language and cultural capital. The relevance of language skills in the labour market positioning of migrated academics]. Wiesbaden: Springer VS.

Jungwirth, I. (2014). Migration und MobilitätPerspektiven der Geschlechtersoziologie [Migration and mobility-Gender sociology perspectives]. In B. Rendtorff, B. Riegraf, \& C. Mahs (Eds.), 40 Jahre Feministische Debatten. Resümee und Ausblick [40 years of feminist debates. Summary and outlook] (pp. 209-227). Weinheim and Basel: Beltz Juventa.

Kofman, E. (2012). Gender and skilled migration in Europe. Cuadernos de Relaciones Laborales, 30(1), 63-89.

Kroh, M., Kühne, S., Goebel, J., \& Preu, F. (2015). The 2013 IAB-SOEP migration sample (M1): Sampling design and weighting adjustment (SOEP Survey Papers No. 271: Series C). Berlin: DIW/SOEP.

Liversage, A. (2009). Vital conjunctures, shifting horizons: High-skilled female immigrants looking for work. Work, Employment and Society, 23(1), 120-141.

Moroşanu, L., \& Fox, J. E. (2013). "No smoke without fire": Strategies of coping with stigmatised migrant identities. Ethnicities, 13(4), 438-456.

Nohl, A.-M., Ofner, U. S., \& Thomsen, S. (2010). Hochqualifizierte Bildungsausländerlnnen in Deutschland: Arbeitsmarkterfahrungen unter den Bedingungen formaler Gleichberechtigung [Highly qualified foreign degree-holders in Germany: Labour market experiences under conditions of formal equality]. In A.-M. Nohl, K. Schittenhelm, O. Schmidtke, \& A. Weiß (Eds.), Kulturelles Kapital in 
der Migration. Hochqualifizierte Einwanderer und Einwanderinnen auf dem Arbeitsmarkt [Cultural capital in migration: Highly qualified immigrants on the labour market] (pp. 67-82). Wiesbaden: VS Verlag für Sozialwissenschaften.

Nowicka, M. (2013). Positioning strategies of Polish entrepreneurs in Germany: Transnationalizing Bourdieu's notion of capital. International Sociology, 28(1), 29-47.

Sienkiewicz, J. J., Tucci, I., Barglowski, K., \& Faist, T. (2017). Contrast groups based on spatial mobility and social position for use in the qualitative sample. Technical report of the "Transnational mobility and social positions in the European Union" (TransMob) project (152). Bielefeld: COMCAD Working Paper Series.

Simón, H., Ramos, R., \& Sanromá, E. (2014). Immigrant occupational mobility: Longitudinal evidence from Spain. European Journal of Population, 30(2), 223-255.

SOEP Group. (2018). SOEP-Core v33.1-Documentation of person-related status and generated variables in SPGEN (SOEP Survey Papers No. 483: Series D). Berlin: DIW/SOEP.

SOEP. (2019). Socio-economic panel, data from 1984-2017 (version 34) [Data set]. https://doi.org/ 10.5684/soep.v34

Strauss, A. L. (1987). Qualitative analysis for social scientists. Cambridge: Cambridge University Press.

TNS Infratest Sozialforschung. (2014). Erhebungsinstrumente des IAB-SOEP-Migrationssamples 2013: Übersetzungshilfen (englisch, polnisch, türkisch, rumänisch, russisch) [Survey instruments of the IAB-SOEP migration sample 2013: Translation guide (English, Polish, Turkish, Romanian, Russian)] (SOEP Survey Papers No. 219: Series A). Berlin: DIW/SOEP.

TNS Infratest Sozialforschung. (2016). Erhebungsinstrumente des IAB-SOEP-Migrationssamples 2015: Integrierter Personen-Biografiefragebogen, Stichprobe
M2, Erstbefragte [Survey instruments of the IABSOEP-migration sample 2015: Integrated individual biography questionnaire, sample $\mathrm{M} 2$, initial survey] (SOEP Survey Papers No. 368: Series A). Berlin: DIW/SOEP.

Vianello, F. A. (2014). Ukrainian migrant workers in Italy: Coping with and reacting to downward mobility. Central and Eastern European Migration Review, 3(1), 85-98.

Vianello, F. A., \& Toffanin, A. M. (2020). Young adult migrants' representation of ethnic, gender and generational disadvantage in Italy. Ethnic and Racial Studies, 1-19. https://doi.org/10.1080/ 01419870.2020 .1726429

Vidal-Coso, E., \& Miret-Gamundi, P. (2014). The labour trajectories of immigrant women in Spain: Are there signs of upward social mobility? Demographic Research, 31, 337-380.

Wagner, G. G., Göbel, J., Krause, P., Pischner, R., \& Sieber, I. (2008). Das Sozio-oekonomische Panel (SOEP): Multidisziplinäres Haushaltspanel und Kohortenstudie für Deutschland. Eine Einführung (für neue Datennutzer) mit einem Ausblick (für erfahrene Anwender) [The socio-economic panel (SOEP): Multidisciplinary household panel and cohort study for Germany. An introduction (for new data users) with an outlook (for experienced users)]. Wirtschafts- und Sozialstatistisches Archiv, 2(4), 301-328.

Weiss, A. (2002). Raumrelationen als zentraler Aspekt weltweiter Ungleichheiten [Spatial relations as a central aspect of worldwide inequalities]. Mittelweg 36, 11(2), 76-92. Retrieved from https://nbn-resolving. org/urn:nbn:de:0168-ssoar-122203

Weiss, A. (2006). Comparative research on highly skilled migrants. Can qualitative interviews be used in order to reconstruct a class position? Forum: Qualitative Social Research, 7(3). https://doi.org/http://dx.doi. org/10.17169/fqs-7.3.136

\section{About the Author}

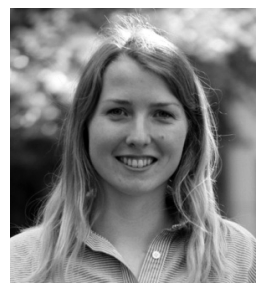

Anica Waldendorf is a PhD Researcher at the European University Institute in Florence, Italy. She combines quantitative and qualitative methods to study social inequality, social position and migration, particularly from a gender perspective. 